\title{
On the occurrence of the fishing Cat Prionailurus viverrinus BENNET, 1833 (CARNIVORA: FELIDAE) IN COASTAL KERALA, INDIA
}

\author{
Ranjini Janardhanan ${ }^{1}$, Shomita Mukherjee ${ }^{2}$, P.V. Karunakaran ${ }^{3}$ \& Ramana Athreya ${ }^{4}$ \\ 1,2,3 Sálim Ali Centre for Ornithology and Natural History (SACON), Anaikatty Post, Coimbatore, Tamil Nadu 641108, \\ India \\ ${ }^{4}$ Indian Institute of Science Education and Research (IISER), 900, NCL Innovation Park, Dr Homi Bhabha Road, Pune, \\ Maharashtra 411008, India \\ ${ }^{1}$ jranjini@gmail.com, ${ }^{2}$ shomitam@gmail.com (corresponding author), ${ }^{3}$ karunakaran.pv@gmail.com, \\ ${ }^{4}$ rathreya@iiserpune.ac.in
}

ISSN

Online 0974-7907 Print 0974-7893

OPEN ACCESS

\begin{abstract}
The Fishing Cat Prionailurus viverrinus is classified as Endangered in the IUCN Red List and yet its distribution range within India is not resolved. In spite of its potential habitat being present in coastal Kerala, there are only a few, unsubstantiated records of the cat. Moreover, its occurrence in Sri Lanka strengthens the possibility of its presence (historical or current population) in southern India, including Kerala. This survey was conducted to assess the occurrence of the Fishing Cat in coastal Kerala through personal informal interviews with local people and molecular analysis of scats. The study failed to find any evidence of the occurrence of Fishing Cat in the coastal areas of Kerala. We discuss two possibilities - one, of the species existing earlier but driven to extinction in recent decades, due to high levels of land conversion through anthropogenic activities in these areas and the other of the Fishing Cat having never occurred in coastal Kerala. A speculative reasoning for its absence from the region could be related to the difference in salinity levels between the eastern and western coasts of India which has already been documented. Moreover, fewer freshwater sources merge into the sea in coastal areas of Kerala as compared to the eastern coast of India. This could limit the distribution of the Fishing Cat. The argument was also supported by the lack of any authentic report till date or of local names for the Fishing Cat in the region.
\end{abstract}

Keywords: Coastal Kerala, distribution, Fishing Cat, scat analysis.

Abbreviations: DNA - Deoxyribonucleic Acid; GADM - Global Administrative areas; IUCN - International Union for the Conservation of Nature; PCR - Polymerase Chain Reaction
This study was undertaken to evaluate unauthenticated records of the presence of the Fishing Cat Prionailurus viverrinus (Bennett, 1833) along coastal Kerala, which could help establish the link to its distribution in Sri Lanka. Owing to the severity of threats to its habitat and its depleting population, the Fishing Cat is included in Schedule I of the Indian Wildlife (Protection) Act (Anonymous 1972) and listed as Endangered in the 2010 assessment of the IUCN Red List of Threatened Species (Mukherjee et al. 2010a). This medium-sized cat is one among the 15 species of cats in India (Nowell \& Jackson 1996), and weighs 6-16 kg (Sunquist \& Sunquist 2002). Wetlands such as mangroves, rivers, ponds and canals are potential habitats for this cat.

The Fishing Cat is discontinuously distributed in Asia and occurs in India, Pakistan (Sindh), Nepal, Bangladesh, Sri Lanka, Thailand, Cambodia and Java (Pocock 1939; Cutter 2009; Cutter \& Cutter 2009). India and Sri Lanka are strongholds for the Fishing Cat. There is no authentic

DOI: http://dx.doi.org/10.11609/JoTT.o3780.5569-73 | ZooBank: urn:Isid:zoobank.org:pub:5235A640-A54E-49C0-B754-8212EDDFA331

Editor: P.O. Nameer, Kerala Agricultural University, Thrissur, India

Date of publication: 26 March 2014 (online \& print)

Manuscript details: Ms \# 03780 | Received 28 September 2013 | Final received 14 March 2014 | Finally accepted 15 March 2014

Citation: Janardhanan, R., S. Mukherjee, P.V. Karunakaran \& R. Athreya (2014). On the occurrence of the Fishing Cat Prionailurus viverrinus Bennet, 1833 (Carnivora: Felidae) in coastal Kerala, India. Journal of Threatened Taxa 6(3): 5569-5573; http://dx.doi.org/10.11609/JoTT.03780.5569-73

Copyright: () Janardhanan et al. 2014. Creative Commons Attribution 3.0 Unported License. JoTT allows unrestricted use of this article in any medium, reproduction and distribution by providing adequate credit to the authors and the source of publication.

Funding: The project was funded by Panthera Corporation, New York for field work and The Indian Institute for Science Education and Research (IISER), Pune for laboratory space, equipment and chemicals.

Competing Interest: The authors declare no competing interests.

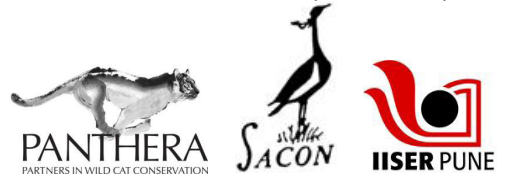

Acknowledgements: This study emanates from a larger study supported by Panthera Corporation, New York. We thank Director, SACON for facilitating and supporting the work. We thank IISER, Pune for laboratory space and chemicals, the Forests and wildlife Department of Kerala for permits, logistic help and discussions; Mahatma Gandhi University, School of Environmental Sciences, Kottayam and IISER, Trivandrum for accommodation in their guest houses. We thank M. Ravi, our driver during the field survey. Several people we interacted with, provided information on locations of sites, especially Ajay, Ayyapan, Chacko, Charan, Christopher, Prasanth, Rajeevan, Subramany and Toms for providing information and accompanying us to various sites. We also thank Ginson, Subin and Thangappan for information on the wild cats they had seen. We are grateful to Hema for facilitating accommodation at Trivandrum. We thank Mansi, Gouri and many others in the laboratory at IISER, Pune for helping us through stressful troubleshooting as well as making our stay and work enjoyable. We are grateful to Velumani and Prachi who helped enormously with troubleshooting as well as with ordering and suggesting various DNA extraction kits when we needed them urgently. We thank the editor and reviewers of the manuscript for their comments. 
report from peninsular Malaysia and its distribution in Laos and Sumatra is disputed (Duckworth et al. 1999, 2009). Within India, the Fishing Cat is primarily distributed in the eastern parts (West Bengal, Assam, Orissa, parts of Andhra Pradesh) and along the foothills of the Himalaya in the Terai tract (Pocock 1939; Sunquist \& Sunquist 2002). There are records from Keoladeo Ghana National Park, Bharatpur (Nowell \& Jackson 1996; Sunquist \& Sunquist 2002; Mukherjee et al. 2012) and one recent camera trap record from Ranthambhore Tiger Reserve (Sadhu \& Reddy 2013). Since the distribution of this cat continues into Sri Lanka, it is expected to occur in southern India. Despite the presence of wetlands and mangroves along the western coast, the occurrence of the Fishing Cat in this region is contentious (Prater 1971; Sunquist \& Sunquist 2002; Menon 2003). Some authors have speculated a recent extirpation of the species from this region due to habitat loss (Karanth 1986; Nowell \& Jackson 1996; Sunquist \& Sunquist 2002; Kumara \& Singh 2007). On the other hand, there are recent, though unsubstantiated, reports of the Fishing Cat from Kannur, Kumarakom Mangroves and Periyar Tiger Reserve in Kerala (http://wild-cat.org/viverrinus/ fishing-cat/index.htm?pv-distribution.htm, accessed on $20^{\text {th }}$ August 2013; http://www.periyartigerreserve.org/ check_list/mammals.pdf, accessed on $14^{\text {th }}$ March 2014). Pocock (1939) questions the validity of the Malabar Coast (which in the 1930s would include almost the entire western coast of India) as the locality of the type specimen of the species. He remarks that this could be an assumption since the donor submitted a specimen of a langur from the Western Ghats along with the Fishing Cat specimen, though notes on the specimen mention the locality as just 'India'. The record from Periyar Tiger Reserve too is not substantiated with photographic or genetic evidence and so remains speculative.

One scenario suggests that the species was present in this region historically and at present occurs in small populations, in danger of extinction, or has already been extirpated from this region. Alternatively, the possibility of the cat having never occurred here also cannot be rejected. Solving this is important, not just to enable conservation of this Endangered (Mukherjee et al. 2010a) cat but also to trace its historical dispersal into Sri Lanka.

Given the background, the present survey was undertaken to evaluate Fishing Cat distribution in this region. We surveyed potential habitats in coastal Kerala for Fishing Cat through scat collection and assignment of scats to species using molecular tools. We also interviewed local inhabitants for information on the

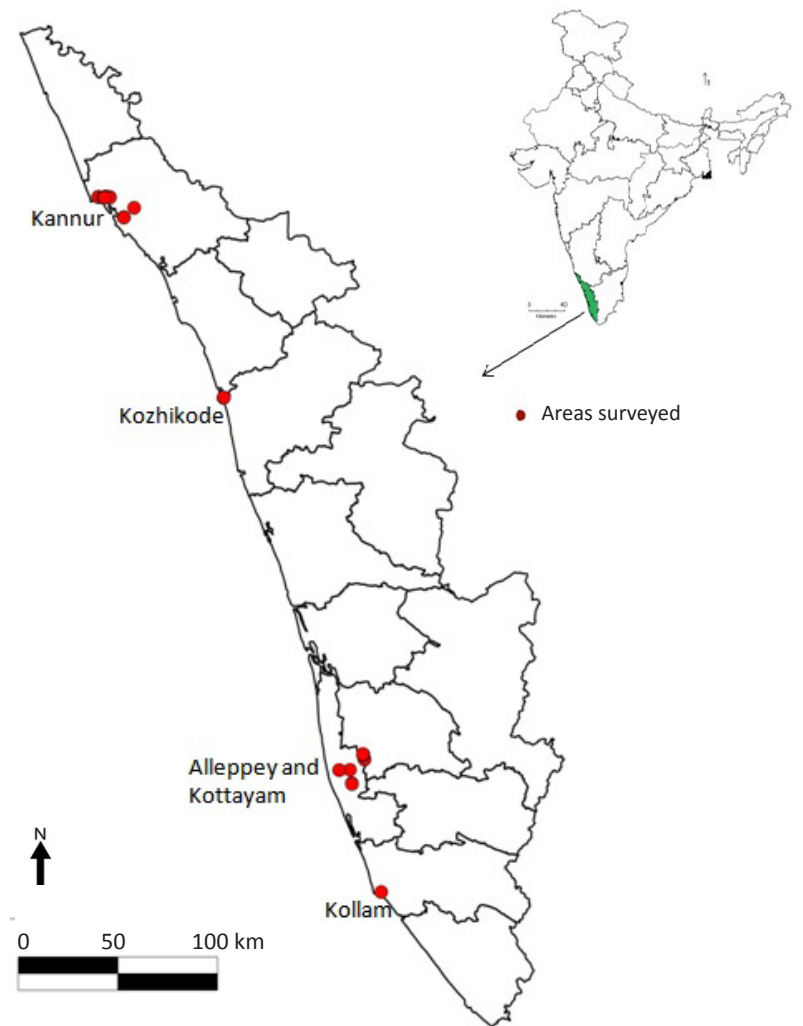

Figure 1. Map showing the areas surveyed in Kerala The inset shows the map of India with Kerala state highlighted. The name of the districts is mentioned in the map and the points in red are the localities studied during the survey.

Source: Data extracted from GADM version 1.0

Table 1. Places surveyed where habitat observations were made and scat samples were collected

\begin{tabular}{|c|c|c|}
\hline District & Locality & Habitat type \\
\hline \multirow{4}{*}{ Kannur } & Ezhom in Pazhyangadi & $\begin{array}{l}\text { Mangroves, aquaculture } \\
\text { farm, paddy fields }\end{array}$ \\
\hline & Chempallikunde & $\begin{array}{l}\text { Aquaculture farm, } \\
\text { abandoned paddy fields }\end{array}$ \\
\hline & Ramapuram East and West & $\begin{array}{l}\text { Vegetation dominated } \\
\text { by Typha sp., degraded } \\
\text { mangroves }\end{array}$ \\
\hline & $\begin{array}{l}\text { Pappinissery in Chungam, } \\
\text { Mayyil Panchayat, } \\
\text { Koduvally in Thalassery }\end{array}$ & $\begin{array}{l}\text { Relatively intact mangroves, } \\
\text { aquaculture farms }\end{array}$ \\
\hline $\begin{array}{l}\text { Kozhikode } \\
\text { and } \\
\text { Malappuram }\end{array}$ & Kadalundi & $\begin{array}{l}\text { Mangrove islands } \\
\text { (degraded) }\end{array}$ \\
\hline Kottayam & Neelamperoor & $\begin{array}{l}\text { Paddy field and vegetation } \\
\text { dominated by Typha } s p .\end{array}$ \\
\hline \multirow{5}{*}{ Alleppey } & Kavalam & $\begin{array}{l}\text { Tall grass, abandoned paddy } \\
\text { fields }\end{array}$ \\
\hline & Boothapandi Kayal & Temple pond \\
\hline & Thankankary & $\begin{array}{l}\text { Tall grass, abandoned paddy } \\
\text { fields }\end{array}$ \\
\hline & Kanjoor & Tall grass and trees \\
\hline & Judge 6000 East & Paddy fields and canals \\
\hline Kollam & Ashramam & Highly disturbed mangroves \\
\hline
\end{tabular}


Fishing Cat and its potential habitat in the locality.

Method: The survey localities were initially selected based on the presence of relatively intact mangrove patches and earlier unauthenticated records of the species. The survey lasted for a week (20-27 January 2013) and several localities under five districts were visited (Table 1, Fig. 1). Upon reaching a locality, we contacted naturalists, research institutes and forest department personnel who could provide us with information on possible records of the cat or of potential habitats (wetlands, mangroves and marshy areas). We also interacted with people in the locality for any information on small cats in the area. A few people whom we interviewed claimed to have seen 'wild' cats and they were asked to describe the cat through its tail length (e.g., was the tail long or short?), body size (would the size compare with house cat or dog?), height of the cat, length of legs, coat pattern and any other behaviour if observed.

Scat collection and analysis: Based on information obtained on habitats, we visited specific localities for sample collection. We followed existing paths to survey an area. All scats encountered were collected since visual assignment to predators is difficult given that several small carnivores coexist in an area. Scats were collected in separate vials. Special care was taken while collecting, to avoid contact with bare hands in order to prevent contamination across scats. Very old and degraded (disintegrated and without the smooth outer coating) scats were not collected.

Scats samples were carried to the laboratory where alcohol was added to preserve DNA for further analysis. Faecal DNA was extracted using commercially available extraction kits from QIAGEN (QIAAmp) and scats were assigned to the predator species by using the felid specific primer for the $16 \mathrm{~s}$ rRNA region and a restriction digestion with Hae III, Ase I and Dpn I, following Mukherjee et al. (2010b).

Results: We visited five districts, Kannur, Kozhikode, Kottayam, Alleppey and Kollam (Table 1). All localities visited were severely disturbed with higher levels of disturbance in southern Kerala.

The local people interviewed in places we visited could not provide any information on Fishing Cat presence. Moreover, there was no local name for the species. The descriptions by locals of cats they had sighted matched either the Jungle Cat or Rusty-spotted Cat (Image 3). There was one past unconfirmed record of a Fishing Cat in the 1990s that was rescued from a well near Parassinikadavu Snake Park in Kannur District. The cat was held in captivity at the Snake Park until it died in 1993. Subsequently, the skin of the cat was kept at the Snake Park until a fire left no trace of it. There are no further details available nor is there any photographic evidence and the record remains unauthenticated. We also contacted the person (P.C. Rajeevan) who claimed to have seen a Fishing Cat near Parassinikadavu temple, Kannur in 2009 (http://wild-cat.org/viverrinus/fishingcat/index.htm?pv-distribution.htm, accessed on 20 August 2013). He told us that he assumed it was a Fishing Cat as he saw it swimming across the river. The record by Jafer Palot (http://wild-cat.org/viverrinus/ fishing-cat/index.htm?pv-distribution.htm., accessed on 20 August 2013) is not supplemented with photographic evidence.

Scat analysis: We collected 51 scats from all the sites visited (Image 1). Of these, 14 were positive for felids. Restriction digestions were carried out on 10 scats. Four scats had insufficient predator DNA after amplification with felid primers and were not included in the restriction digestions. We could identify six jungle cats and two house cats from the restriction digestion profiles (Image 2). Restriction profiles of PCR products from two scats did not give clear results and were classified as unknown. No scat was assigned to Fishing Cat.

Discussion: Our survey for Fishing Cat in the coastal areas of Kerala did not suggest the current existence of a population in the region. Interviews with people in the survey sites, observations on the habitat and assignment of scats to predators using molecular tools failed to provide any authentic indication of its presence.

The local people were familiar with other cats present in the region such as the Jungle Cat, Leopard Cat and Rusty-spotted Cat and could describe them well. They

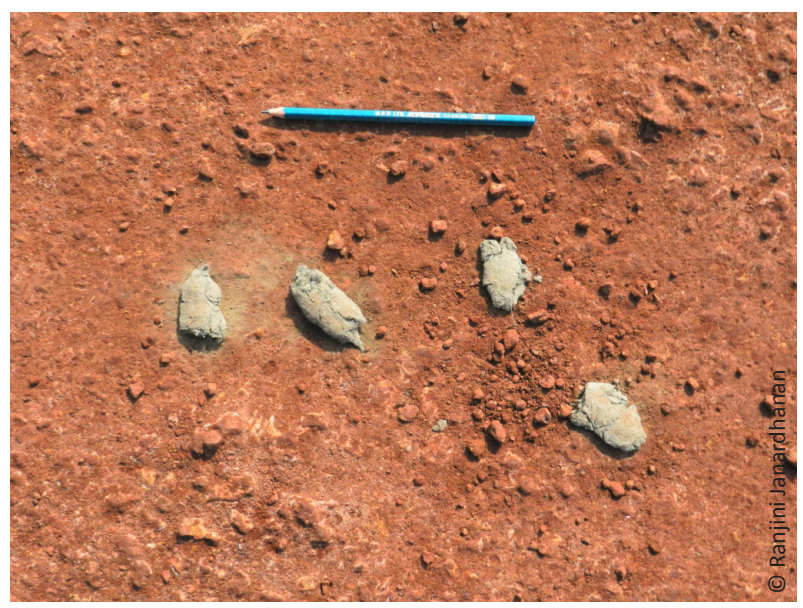

Image 1. Scats along an aquaculture farm in Kannur. Laboratory analysis of scats from here assigned them to Jungle Cat. 


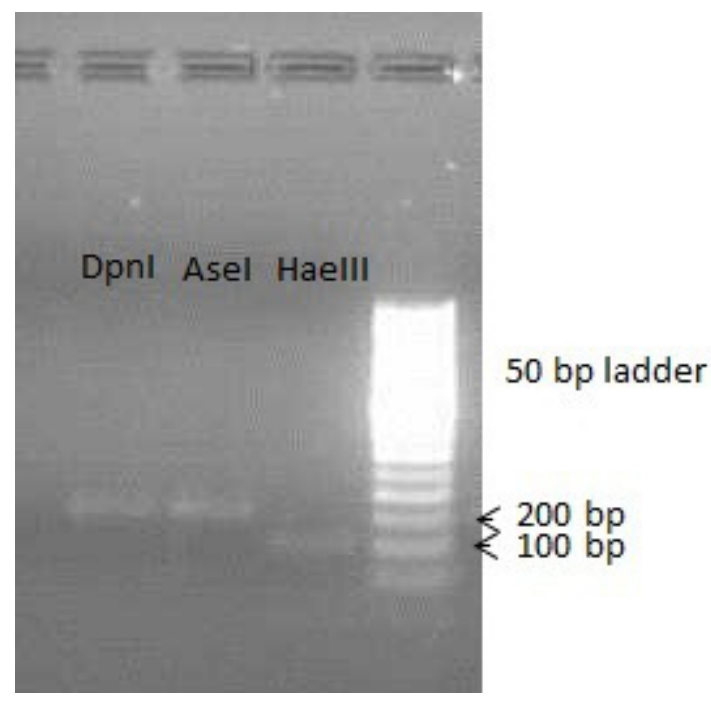

Image 2. Restriction digestion (RFLP) profiles of three enzymes HaellI, Asel and Dpnl. The amplified product of the 16srRNA gene of the mitochondrial DNA is $\mathbf{2 1 0}$ base pairs long. Any result that shows a smaller band indicates digestion has taken place and the amplicon is cut. Here HaellI has cut the amplicon but Asel and Dpnl have not. This profile matches that of a house cat. MtDNA of different species of cats show different profiles with these three enzymes thus aiding identification. (C) Ranjini Janardhanan

even have local names for these cats. However, there seemed to be no local name for the Fishing Cat unlike in other areas of the country where Fishing Cats are seen (Tiasa Adhya pers. comm. 2013). The cat is fairly large and at 6-16 kg body mass (Sunquist \& Sunquist 2002), is much larger than the Jungle Cat (average body mass $5 \mathrm{~kg}$ ), Leopard Cat (average body mass $3 \mathrm{~kg}$ ) and Rusty Spotted Cat (average body mass <2kg) (Pocock 1939; Sunquist \& Sunquist 2002). If it did occur along human dominated coastal Kerala, it would perhaps not go unnoticed, given its size. Additionally, during scat collection we did not come across any site that had large depositions of scat, behaviour peculiar to the Fishing Cat seen across its distribution range in India (Mukherjee et al. 2012).

The results were surprising as coastal areas in Kerala are rich in water bodies, mangroves and marshes that are similar to the habitat of the Fishing Cat elsewhere. From our results we cannot conclude if Fishing Cats have only relatively recently been extirpated from this region or had never occurred along coastal Kerala.

We met Mr P.C. Rajeevan, one of the two people who claim to have seen the Fishing Cat in Kannur District in 2009. He clarified that he assumed it was a Fishing Cat because it was swimming across the Ramapuram River. Dr. Jafer Palot was the other person who claims to have seen the cat twice in Kannur, one was the captive individual in the Parassinikadavu Snake Park sometime in the early 1990s, of which there is no photographic

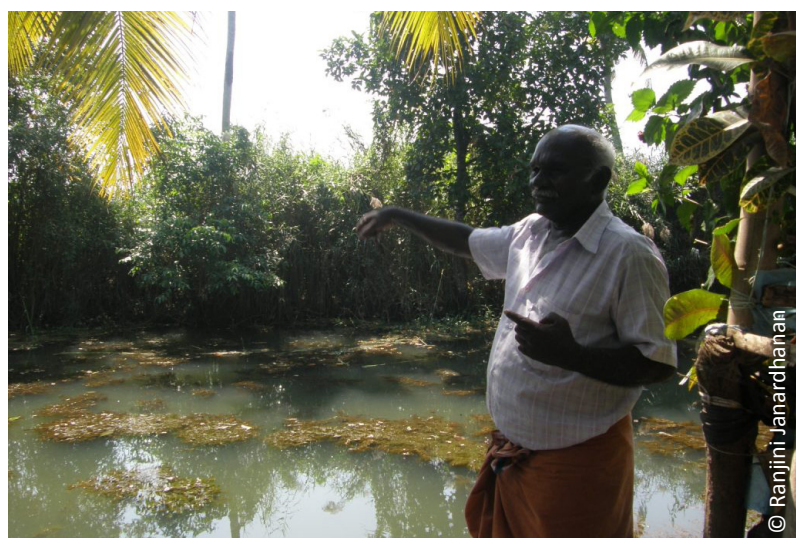

Image 3. A local showing a patch opposite his house in Alleppey where a wild cat visits regularly. He said the cat comes to catch fish but the description he gave of the cat (big ears and long legs) matched the Jungle Cat.

or genetic evidence and the other sighting was of an adult at the Chemballikundu mangroves in 1995. He based this identification on the individual he saw at the Snake Park. Since both records are unsubstantiated it is prudent to treat them with caution owing to the several instances of misidentification of Leopard Cats and house cats as Fishing Cats, even by experts (Duckworth et al. 2009, Shomita Mukherjee pers. obs. 2009, 2010, 2014). Furthermore, the state of the mangroves is believed to have improved since the formation of the Kerala Coastal Zone Management Authority in 1998 (http://www. envfor.nic.in/legis/crz/1001.html, accessed on 21st August 2013). Despite this, in our current survey we found the mangroves to be in a devastated condition. Hence, it is reasonable to accept that in the 1990s when these sightings were made, the habitat was in a worse state. From our present observations we reason that it would not be feasible for the Fishing Cat to survive in such small fragments of highly polluted mangroves.

One possibility could be that the species was present here earlier and could have recently been extirpated as suggested by Karanth (1986) and Kumara \& Singh (2007). Our observations on the present state of potential habitat of the species reveal alarming levels of disturbance due to anthropogenic activities. These habitats are either completely destroyed for civil constructions, or have undergone severe land conversion. Many mangrove patches have been converted to coconut grooves, paddy fields or aquaculture farms. Some aquaculture farms are abandoned but retain water in them. The wetlands, canals, marshes and mangroves that we visited were all deeply fragmented into small patches of less than $1 \mathrm{~km}^{2}$ area and polluted with waste from neighbouring urban sprawls (Images $4 \& 5$ ). With such severe disturbance 

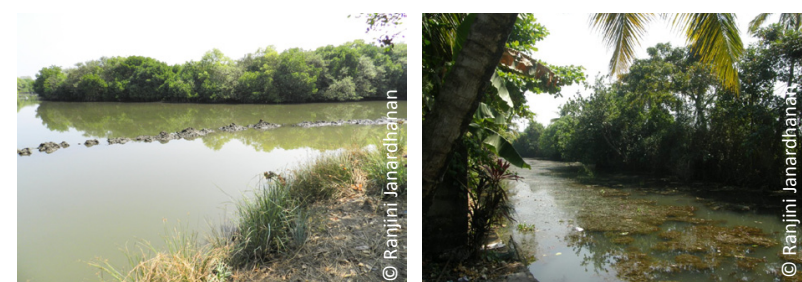

Image 4. Abandoned aquaculture Image 5. Canal in Alleppey. The farm in Kannur District. Originally canals were not just polluted and this was a mangrove patch. clogged but there were no large fish in them that could sustain a 12-15 kg cat.

and fragmentation it is unlikely that the Fishing Cat could currently survive in these patches. Moreover, the backwater canals seem to be devoid of any large fish that could sustain a population of a medium-sized felid. However, in eastern and northern India the Fishing Cat occurs around human habitations (Mukherjee et al. 2012). Furthermore, in rural West Bengal, locals farm large fish in their home ponds and this perhaps aids the persistence of the Fishing Cat. Another threat for all small wild felids that we perceived during this study was that local people were not receptive to the presence of small cats as they predate on their poultry. An example is a case from Alleppey where a female Rusty Spotted Cat was trapped and killed, and its litter though adopted by local people, did not survive.

The second argument would be that the species never occurred in this region. This is puzzling especially since their dispersal into Sri Lanka could only have occurred through southern India. It is possible that this happened through southeastern India (Andhra Pradesh/ Tamil Nadu).

We hypothesize that the higher salinity levels along the western coast as compared to the eastern coast (Shankar \& Shetye 2001) could be a factor preventing Fishing Cats from colonising the western coast of India. Further, the extent of area under wetlands is higher along the eastern coast as compared to the western coast of India. A reason for lower salinity in the eastern coast is also partly due to a larger area under river-fed wetlands when compared with the western coast (Selvam 2003). Though conjectural, salinity being the limiting factor for Fishing Cat distribution along the western coast of India can be tested through niche models. Yet there is a possibility of Fishing Cat presence in inland areas with fresh water sources especially along the Western Ghats and the absence of records from this region is confusing.

We conclude that given our observations on the condition of the wetlands, water bodies, mangroves and canals along coastal Kerala and discussions with

locals, it is unlikely that the Fishing Cat currently occurs in the region. This was supported by results from the scat sampling done in this region. We also hypothesise that the Fishing Cat perhaps never occurred along the western coast of India due to higher salinity levels as compared to the eastern coast. However, this needs to be tested through further analysis using niche models.

\section{References}

Anonymous (1972). The Wild Life Protection Act, 1972. Professional Book Publishers, New Delhi.

Cutter, P. (2009). Report on Camera Trapping and Conservation Status Assessment of Fishing Cats at Khao Sam Roi Yod National Park, Thailand and Surrounding Areas. Fishing Cat Research and Conservation Project, Occasional Report \#5, 10pp.

Cutter, P. \& P. Cutter (2009). Recent sightings of Fishing Cats in Thailand. Cat News 51: 26-27.

Duckworth, J.W, C.R. Shepherd, G. Semiadi, P. Schauenberg, J. Sanderson, S.I. Roberton, T.G. O'brien, T. Maddox, M. Linkie, J. Holden \& N.W. Brickle (2009). Does the Fishing Cat inhabit Sumatra? Cat News 51: 04-09

Duckworth, J.W., R.E. Salter \& K. Khounboline (1999). Status Report on Wildlife in Lao PDR. IUCN, Vientiane, Lao PDR, 275pp.

Karanth, K.U. (1986). Status of wild life and habitat conservation in Karnataka. Journal of Bombay Natural History Society 83 (Supplement): 166-179

Kumara, H.N. \& M. Singh (2007). Small carnivores of Karnataka: distribution and sight records. Journal of the Bombay Natural History Society 104: 155-162

Menon, V. (2003). A Field Guide to Indian Mammals. Dorling Kindersley (India) Pvt. Ltd. and Penguin Book India (P) Ltd., New Delhi, 201pp.

Mukherjee, S., J. Sanderson, W. Duckworth, R. Melisch, J. Khan, A. Wilting, S. Sunarto \& J.G. Howard (2010a). Prionailurus viverrinus. In: IUCN 2011. IUCN Red List of Threatened Species. Version 2011.2. <www.iucnredlist.org>. Downloaded on 26 April 2012.

Mukherjee, S., C.N. Ashalakshmi, C. Home \& U. Ramakrishnan (2010b). A PCR-RFLP technique to identify Indian felids and canids from scats. BioMed Central Research Notes 3: 159; http://dx.doi. org/10.1186/1756-0500-3-159

Mukherjee, S., T. Adhya, P. Thatte \& U. Ramakrishnan (2012). Survey of the Fishing Cat Prionailurus viverrinus Bennett, 1833 (Carnivora: Felidae) and some aspects impacting its conservation in India. Journal of Threatened Taxa 4(14): 3355-3361; http://dx.doi.org/10.11609/ JoTT.o3199.3355-61

Nowell, K. \& P. Jackson (eds.) (1996). Wild Cats, Status Survey and Conservation Action Plan. IUCN, Gland Switzerland, 382pp.

Prater, S.H. (1971). The Book of Indian Animals - $4^{\text {th }}$ Impression. Bombay Natural History Society, Bombay, and Oxford University Press, Mumbai, 324pp.

Pocock, R.I. (1939). The fauna of British India, including Ceylon and Burma. Mammalia 1: Primates and Carnivora. (In part). $2^{\text {nd }}$ Edition. (Reprint edition, 1985 NewDelhi: Today and Tomorrow's Printers and Publishers). Chicago: University of Chicago Press.

Sadhu, A. \& G.V. Reddy (2013). First evidence of Fishing Cat in the Ranthambhore Tiger Reserve, Rajasthan, India. Cat News 58: 36-37.

Selvam, V. (2003). Environmental classification of mangrove wetlands of India. Current Science 84(6): 757-765

Shankar, D. \& S.R. Shetye (2001). Why is the mean sea level along the Indian coast higher in the Bay of Bengal than in the Arabian sea? Geophysical Research Letters 28: 563-565.

Sunquist, M.E. \& F.C. Sunquist (2002). Wild Cats of the World University Chicago Press, Chicago, 452pp.

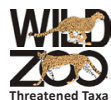

